\title{
Arqueologia no licenciamento ambiental: uma etnografia de cientistas e suas burocracias
}

Archaeology in environmental licensing: an ethnography of scientists and their bureaucracies

Marcus A. S. Wittmann

\section{(2) OpenEdition}

\section{Journals}

Edição electrónica

URL: http://journals.openedition.org/aa/3515

DOI: 10.4000/aa.3515

ISSN: 2357-738X

\section{Editora}

Programa de Pós-Graduação em Antropologia Social (UnB)

Edição impressa

Data de publição: 1 junho 2019

Paginação: 217-252

ISSN: 0102-4302

\section{Refêrencia eletrónica}

Marcus A. S. Wittmann, «Arqueologia no licenciamento ambiental: uma etnografia de cientistas e suas burocracias», Anuário Antropológico [Online], v.44 n.1 | 2019, posto online no dia 06 julho 2019, consultado o 28 abril 2021. URL: http://journals.openedition.org/aa/3515 ; DOI: https://doi.org/ $10.4000 / a a .3515$

\section{(c) $(1)(9)$}

Anuário Antropológico is licensed under a Creative Commons Atribuição-Uso Não-Comercial-Proibição de realização de Obras Derivadas 4.0 International. 


\title{
Arqueologia no licenciamento ambiental: uma etnografia de cientistas e suas burocracias
}

\author{
Marcus A. S. Wittmann
}

Universidade Federal do Rio Grande do Sul - Brasil

\begin{abstract}
From the point of view of an archaeologist it can be difficult to believe that there are cultural realms to be investigated right in front of our eyes, in our very actions or words, or in the movement of the trowel. Or that the everyday archaeological routines and procedures that seem so ordinary to us might seem truly extraordinary if viewed from another standpoint. (Matt Edgeworth, 2006: xiv-xv)
\end{abstract}

\section{Sobre arqueologia e licenciamento ambiental}

A inserção de diferentes práticas científicas nos trâmites do licenciamento ambiental é causa de diversos debates, posições, análises e interpretações. No âmbito das ciências humanas - nas quais tanto a arqueologia quanto a antropologia se encontram -, uma das grandes perguntas que é feita gira em torno da possibilidade de se exercer metodologicamente e teoricamente um trabalho de campo que consiga ir além do estritamente solicitado pela legislação e possibilitado pelos prazos e orçamentos. A pesquisa aqui apresentada é fruto de uma dissertação de mestrado (Wittmann, 2018), a qual visou lançar um olhar etnográfico para a prática arqueológica no licenciamento ambiental, abrangendo tanto questões relativas ao trabalho de campo quanto aos constrangimentos legais, burocráticos, políticos, econômicos e também científicos que perpassam a confecção de relatórios técnicos e a definição de sítios arqueológicos.

No que tange à prática arqueológica nesse contexto, as discussões e análises de dentro do campo, publicadas em artigos ou apresentadas em congressos, ainda têm seu foco ou em uma exposição acerca da metodologia e resultados de pesquisa, ou em uma crítica a um dito conluio entre arqueologia, capitalismo e projetos desenvolvimentistas. Para se ter uma ideia do tamanho da relação entre arqueologia e licenciamento ambiental, desde 2002, quando a primeira legislação específica referente à prática arqueológica no licenciamento ambiental foi publicada (Portaria 230/2002), os processos de arqueologia protocolados no Instituto do Patrimônio Histórico e Artístico Nacional (Iphan) referentes à construção de empreendimentos 
correspondem a quase $90 \%$ dos protocolos totais. Olhando para os últimos anos, a partir de 2015 - quando uma nova legislação entrou em vigor (Instrução Normativa $01 / 2015$ ) -, esse número pula para $95 \%{ }^{1}$. Assim sendo, a prática arqueológica no licenciamento ambiental não é apenas causa de um caloroso debate, mas também a principal fonte de trabalho e pesquisa no campo da arqueologia no Brasil.

Meu principal objetivo com esta pesquisa, frente a esse tema quente da relação entre ciência e licenciamento ambiental, foi lançar um outro olhar sobre essa problemática. A abordagem etnográfica nesse caso possibilita trazer uma visão de dentro desse embate, através das falas de diferentes arqueólogos(as), e de fora dele, através de uma análise baseada na antropologia da ciência. Pretendo demonstrar, ao longo destas páginas, não apenas as interpretações acerca desse tema provindas da minha dissertação, mas também a importância de uma etnografia de uma ciência social, humana, nesse contexto do licenciamento ambiental, sendo ele um campo profícuo e rico tanto para a antropologia quanto para a arqueologia.

Explicito aqui o meu lugar particular no e em campo: minha formação acadêmica inicial foi voltada para a arqueologia, e minha experiência profissional nessa área se deu principalmente em processos de licenciamento ambiental. Deste modo, ao fazer uma etnografia da arqueologia, transito entre algo familiar, mas com um olhar voltado para problematizar, descrever, analisar e, de certa forma, transformar esse familiar em exótico. Minha experiência na área da arqueologia possibilitou uma inserção no campo dessa pesquisa de um modo favorável, pois já conhecia tanto os diferentes trâmites que abrangem a prática da arqueologia no licenciamento ambiental quanto vários atores entrevistados na pesquisa (seja por congressos ou trabalhos conjuntos). Essa minha identidade híbrida, entre antropólogo e arqueólogo, entre quem observa e quem participa, me leva também a assumir um papel de diplomata (Latour, 2004), ao procurar um diálogo, estabelecer negociações e possibilidades entre partes destoantes, se não opostas, como muitos definem a arqueologia e o licenciamento ambiental. Dessa forma, minha pesquisa foi pensada também para ser lida tanto por antropólogos quanto por arqueólogos.

A etnografia da prática arqueológica, trabalhada principalmente por Edgeworth (2003, 2006), conversa tanto com a perspectiva pós-processual da arqueologia, a qual entende a disciplina e a produção de um conhecimento sobre o passado como uma produção política e social feita no presente, quanto com a teoria ator-rede da antropologia da ciência (Latour, 2011), a qual propicia um entendimento dos diferentes atores humanos e não humanos atuantes no processo de constituição e 
estabilização de fatos científicos. Deste modo, a análise proposta pela etnografia da prática arqueológica abarca diferentes aspectos da construção do conhecimento arqueológico, desde o trabalho de prospecção e de escavação, até a análise dos dados e objetos em laboratório, a interação com a comunidade, com atores não humanos, as ações de educação patrimonial, a relação com os empreendedores e com o órgão fiscalizador, e a produção de relatórios técnicos, entre outros. A proposta desta pesquisa é voltar sua atenção para as atividades culturais, sociais e políticas dos(as) arqueólogos(as) no presente, através das quais a visão acerca do passado é feita possível (Edgeworth, 2010:53), e, dentro do âmbito do licenciamento ambiental, como é dada a produção de conhecimento sobre uma área e/ou um patrimônio específico que possui um interesse estatal ou da iniciativa privada. Dentro do escopo deste trabalho, meu esforço consistiu em ouvir e entender o que os atores têm a dizer, e seguir suas práticas e discursos nas trilhas de papel dos empreendimentos das quais fazem parte ${ }^{2}$, evidenciando os conflitos e constrangimentos burocráticos, científicos, políticos e sociais pelos quais a construção do conhecimento arqueológico passa no licenciamento ambiental.

Os diferentes atores espalhados por essa rede sociotécnica, sejam eles burocratas, arqueólogos(as), empreendedores ou documentos burocráticos e legislativos, possuem agências diferentes que proporcionam maior sustentação e estabilidade da rede, mediando assim a constituição ou não de outras entidades. A ficha de registro de sítio arqueológico, na qual adentrarei mais adiante, juntamente à legislação vigente, possui mais poder frente à tomada de decisão sobre o que é um sítio arqueológico do que a interpretação e fundamentação científica de um(a) arqueólogo(a) em um relatório técnico. Do mesmo modo, negociações e interesses políticos e possibilidades econômicas influenciam mais na decisão sobre que tipo de estratégia de salvaguarda deve ser tomada acerca de um bem cultural, do que as considerações baseadas em alguma teoria da arqueologia.

Dentre as possibilidades condizentes com o tempo da pesquisa e do campo, decidi fazer um recorte da rede que analisaria: foram abarcados aqui, através de entrevistas, vinte e um(a) arqueólogos(as) que trabalham ou foram formados(as) no Rio Grande do Sul. Nesse escopo há profissionais que atuam no licenciamento ambiental desde os anos 1980, até graduados nos cursos de arqueologia -os quais existem desde 2008 no Rio Grande do Sul. Esses profissionais possuem diferentes cargos - desde donos de empresa até free-lancers - e experiências - de pequenos empreendimentos até obras de grande impacto. Dentro dessa gama de atores, há os 
quatro arqueólogos que, durante o período da pesquisa, atuavam no corpo técnico do setor de arqueologia da Superintendência Estadual do Iphan no Rio Grande do Sul (SE/Iphan-RS). Tive, assim, relatos e interpretações sobre a prática arqueológica no licenciamento ambiental através do olhar de quem produz relatórios e de quem os analisa.

Além desses atores humanos, os documentos burocráticos que fazem parte dos processos de licenciamento são uma fonte essencial para o entendimento de como diferentes entidades e fatos são fabricados, e quais os papéis da ciência, da política e da burocracia nesse âmbito. Frente a isso, foram analisados sessenta processos compostos por projetos, relatórios e outros documentos - referentes a empreendimentos, principalmente de pequeno e/ou médio porte, nos quais os(as) arqueó$\operatorname{logos}($ as) entrevistados(as) trabalharam. Essa trilha de papel é a materialidade que demonstra como os diferentes agentes dessa rede do licenciamento ambiental, principalmente os arqueólogos de dentro e fora do Iphan, não apenas agenciam diferentes entidades, mas também como as produzem e criam um discurso acerca delas.

Os dados e interpretações que serão apresentados aqui são um resumo da etnografia feita na dissertação, entretanto com o foco mais voltado para as entrevistas com os interlocutores. Estas expõem de forma mais geral e ampla as práticas arqueológicas e os trâmites burocráticos do licenciamento ambiental, além dos constrangimentos de caráter científico, burocrático e legal. Deixa-se em segundo plano aqui a pesquisa nos processos de arqueologia e na legislação, ou seja, mesmo que exemplos mais pontuais de empreendimentos e documentos não sejam citados, as questões políticas e econômicas que os rodeiam são levadas em conta na explanação.

Ciência e política, fatos científicos e estado, práticas de conhecimento e práticas burocráticas andam lado a lado, sendo coproduzidas uma pela outra (Jasanoff, 2006). A ciência, assim como o estado, e a arqueologia, assim como o licenciamento ambiental, são colocadas em uma perspectiva na qual podem ser vistas como em ação, em movimento, nas suas constituições, mediações e enredamentos. Essa coprodução de política e ciência mostra como os burocratas e cientistas enredados no licenciamento não são máquinas frias de racionalização objetiva dentro de um sistema rígido e controlador da burocracia estatal. A coprodução desse estado, dessa burocracia e dessa ciência passa por diferentes mediações e agentes que não devem ser invisibilizados e silenciados, mas sim descritos e analisados. Essa perspectiva analítica demonstra como a prática arqueológica e a produção de documentos no licenciamento ambiental não são apenas questões técnicas, burocráticas e enfadonhas, 
mas sim participantes de uma arena de conflitos, disputas e embates. Desse modo,

(...) o licenciamento ambiental, por conta do modo como é regulado no Brasil, se transforma em um espaço de "espetacularização" dos conflitos sociais e ambientais mobilizados pelos grandes empreendimentos industriais, bem como das formas de gestão empresarial hoje adotadas para resolvê-los e domesticá-los. O licenciamento também dá visibilidade aos aparatos regulatórios do Estado brasileiro e aos planos racionais determinados para classificar e gerir seus territórios e populações rumo ao "desenvolvimento" (Bronz, 2011:19).

A utilização do termo "técnico", como algo estéril, neutro e objetivo, simplifica e desumaniza os trâmites da burocracia estatal e do próprio fazer científico nesse contexto. Vários(as) interlocutores(as) apontaram os limites impostos pela burocracia, pelos prazos e orçamentos em suas práticas e construção de conhecimento, tanto em campo, quanto em laboratório. O arqueólogo Joaquim, que atua há mais de uma década no licenciamento ambiental, definiu a prática arqueológica nesse contexto como uma "arqueologia burocrática". Tal termo foi utilizado, pois ele nota que o que rege muitas vezes a metodologia e a teoria arqueológica nesses casos é um checklist pré-pronto de atividades e dados a serem registrados. Ao mesmo tempo, vários(as) interlocutores(as) deram exemplos de possibilidade de maleabilidade desses protocolos rígidos, além de que a própria narrativa deles(as) acerca de seus trabalhos mostra uma faceta social e política que nem sempre é transportada para os relatórios e projetos.

Essa faceta burocrática dos trabalhos arqueológicos no licenciamento ambiental é caracterizada pelos interlocutores como algo oposto ao fazer científico. A burocracia é relatada como um procedimento repetitivo, sem muita reflexividade por parte de quem está inserido nela e geralmente como um corpus legislativo que atrasa os trabalhos, sendo apenas composta de certos trâmites estatais que devem ser seguidos para o prosseguimento das pesquisas. A burocracia, como é vista pelos interlocutores, não tem uma ligação direta com a produção do conhecimento científico, seus métodos e resultados. Contudo, a etnografia demonstrou que há sim uma coprodução e relação entre os trâmites e documentos burocráticos com as práticas e interpretações feitas pelos arqueólogos no licenciamento ambiental.

\section{Arqueólogos(as) burocratas e burocratas arqueólogos(as)}

Durante minha etnografia, notei que é nos documentos burocráticos referen- 
tes às licenças arqueológicas para empreendimentos que se nota mais claramente, de forma materializada, como o conhecimento científico, a legislação, os trâmites burocráticos, as concepções subjetivas dos agentes envolvidos, as negociações políticas e os contextos financeiros estão emaranhados. Nos diferentes processos licenciatórios analisados - os quais abarcam não apenas os projetos e relatórios de arqueologia, mas diversos outros documentos, como troca de e-mails, atas de reuniões, ofícios e pareceres do Iphan, documentos do empreendedor solicitando esclarecimentos ou urgência, entre outros -, não apenas o patrimônio arqueológico é produzido, mas também a política desenvolvimentista do estado e das empresas privadas e as decisões burocráticas do Iphan são constituídas através e por esses documentos.

Quando se fala de Iphan, muitas vezes, principalmente nos discursos dos(as) arqueólogos(as), tende-se a homogeneizar esse instituto. Entretanto, há de se ter cuidados para não descrever e compreender o Iphan como um órgão e uma entidade homogênea e una. Esse instituto é formado por vinte e sete superintendências estaduais - uma em cada estado do Brasil mais o Distrito Federal -, nas quais há um setor de arqueologia, e cada um deles responde à coordenação técnica e $\mathrm{a}(\mathrm{o})$ superintendente. Do mesmo modo que, todas as superintendências estaduais respondem, no que tange questões relativas à arqueologia, ao Centro Nacional de Arqueologia (CNA), que fica em Brasília. Mesmo que haja uma legislação única e trâmites burocráticos específicos para análise de projetos e relatórios, cada SE conta com um corpo técnico distinto, com formações e experiências diferentes, e se insere em conjunturas políticas, econômicas, sociais e científicas - no que se refere ao contexto arqueológico da região, por exemplo - também diferentes. A etnografia efetuada nessa pesquisa não é, deste modo, uma etnografia do Iphan, e nem da Superintendência Estadual do Rio Grande do Sul, mas sim uma descrição e análise acerca das práticas, concepções e do contexto político e científico do setor de arqueologia da SE/Iphan-RS durante um período de tempo específico.

Os processos de arqueologia possuem diversos trânsitos, os quais se espalham por diferentes locais, agenciando e mediando diferentes entidades e atores. Cada processo possui marcas e sinais - sejam textuais ou imagéticas -, assinaturas, anotações e carimbos que ajudam a seguir suas trilhas e os agentes presentes e ausentes. De modo geral, todos os processos seguem etapas comuns, desde a abertura do processo, até a análise do projeto pelo corpo técnico do Iphan, a emissão de um parecer acerca dele para readequação ou não, a emissão da portaria de pesquisa pelo CNA para o(a) arqueólogo(a) coordenador(a), até a entrega do relatório e a emissão 
do parecer final do Iphan. Durante a análise dos processes de arqueologia na SE/ Iphan-RS pude ver como em cada uma dessas etapas vão sendo agregados mais documentos, mais materialidades e diferentes agentes. Não são etapas meramente técnicas ou burocráticas, elas são parte da rede e constituem tanto esses documentos quanto, consequentemente, a prática arqueológica no licenciamento ambiental e o próprio empreendimento.

Analisei esses processos a partir de duas propostas. Uma delas foi entendê-los como artefatos gráficos (Hull, 2012), descrevendo assim suas materialidades através de carimbos, mapas, assinaturas e sua estética, as quais criam efeitos que não são previsíveis e controláveis. Já trabalhei mais densamente com essa proposta em dois trabalhos anteriores (Wittmann, 2017, 2018); deste modo, aqui me aprofundarei na segunda perspectiva. O foco reside tanto na estrutura dos projetos e relatórios organização da teoria, método e levantamento histórico e arqueológico - quanto no modo como as atividades efetuadas em campo são descritas e apresentadas. Dentro desse escopo, segui Lowenkron e Ferreira (2014), as quais estipulam dois tipos de análise em documentos burocráticos: ao longo e contra a corrente. Uma visa entender as intencionalidades declaradas nos documentos, as convenções, legislações, portarias e normativas que os modelam, e outra procura vozes e agências que podem estar invisibilizadas, subjugadas e subalternizadas entre e através dos discursos, mapas, páginas e gráficos desses documentos. Nessa segunda proposta, pode-se ver como pessoas, agências e vozes são reduzidas a escritos, os quais não conseguem transparecer as relações e negociações entre os atores envolvidos na produção dos documentos e do conhecimento científico.

Embora a legislação e a burocracia sejam a linha mestra para a análise e tomada de decisões acerca dos projetos e relatórios, os pareceres técnicos dos arqueólogos da SE/Iphan-RS, e seus próprios depoimentos, mostram que a interpretação dos dados e as solicitações de mudança ou readequação são atravessadas também pelas próprias experiências de campo deles, principalmente em trabalhos de licenciamento ambiental, e pelas perspectivas teórico-metodológicas pessoais. Contudo, o primeiro passo, a primeira etapa de avaliação dos documentos pelos técnicos de arqueologia da SE/Iphan-RS é baseada na legislação que rege cada pedido de licenciamento - seja pela Portaria 230/02 ou pela Instrução Normativa 01/15 (IN $01 / 15$ ) - e, de modo mais amplo, na Lei 3.924 de 1961 (conhecida como a Lei de Arqueologia), e na Portaria 07 de 1988, ambas regendo sobre as definições de sítio e patrimônio arqueológico e sobre a idoneidade técnico-científica dos(as) 
arqueólogos(as) responsáveis. Nesse primeiro momento, essas legislações balizam principalmente as pendências documentais - se falta algum documento e item ou alguma assinatura e rubrica. Diego, arqueólogo da SE/Iphan-RS, narra esse constrangimento burocrático, o qual prende a argumentação do técnico a um certo tipo de narrativa:

Então há um modelo de parecer ${ }^{3}$ onde eu vou buscar qual é o meu documento. É um projeto de avaliação de impacto do nível $\mathrm{III}^{4}$. Então existe um modelo de análise do projeto de avaliação de impacto do nível III, onde ele começa com uma tabela. Essa tabela, ela vai levantar cada um dos incisos, cada um dos itens que o artigo 18 da Instrução Normativa [01/2015] solicita. Então nessa tabela a gente começa nessa avaliação mais formal, por assim dizer, da forma. Se o item 1 está apresentado, sim ou não, e aí nas observações a gente costuma indicar "está na folha tal do volume tal", "o item 2 está apresentado na folha tal do volume tal”, "o item 3 está apresentado" ou "não está apresentado”, e etc.

Apenas após essa conferência, e estando tudo em ordem, parte-se para a análise do conteúdo dos projetos e relatórios. Nessa etapa, a avaliação leva em conta tanto o tipo de empreendimento, principalmente no que tange a seu impacto no solo e na paisagem ${ }^{5}$, quanto o potencial arqueológico da área na qual ele será construído e o contexto arqueológico municipal e regional. Os arqueólogos da SE/Iphan-RS me relataram que todos esses passos são discutidos e conversados entre eles a partir de suas próprias experiências, formações e de seus conhecimentos da legislação. Como relata Diego, arqueólogo da SE/Iphan-RS, sendo o patrimônio arqueológico e sua salvaguarda suas maiores preocupações, o principal em suas análises é "ter uma visão clara do que foi encontrado, de como foi realizado, que tipo de resultados foram obtidos". Entretanto, como dito mais acima, essas análises não são meramente técnicas e objetivas. Nos processos de análise dos projetos e relatórios de arqueologia e de confecção de pareceres técnicos, há diferentes tipos de constrangimentos, sejam burocráticos, hierárquicos, científicos ou políticos, os quais medeiam essas relações e atuam na rede. De nada adianta uma análise e argumentação teórica, metodológica e científica, se não houver uma justificativa plausível e forte dentro de um contexto que abranja não apenas a SE/Iphan-RS, mas as negociações políticas, as preocupações financeiras e as pressões que envolvem um empreendimento específico. Paulo, arqueólogo da SE/Iphan-RS, é categórico sobre essa questão: 
Claro que a gente tem que justificar tudo, por que está fazendo isso, argumentar o porquê, comentar. E isso tem que convencer também a nossa chefia ${ }^{6}$. Porque a nossa chefia, simplesmente se eles quiserem, podem pegar o nosso parecer e dizer "não, aqui eu acho que não precisa arqueologia" e colocar como "não se aplica", mesmo que a gente tenha dito que seja "nível III".

Contudo, esses mesmos constrangimentos burocráticos e legais podem ser revertidos e combatidos pelos(as) próprios(as) técnicos(as) da SE/Iphan-RS. Um caso interessante que me foi relatado foi o de uma Ficha de Caracterização de Atividade (FCA), a qual dá início a todo e qualquer processo de licenciamento ambiental da Instrução Normativa 01/2015. Essa ficha não é necessariamente preenchida por um(a) arqueólogo(a), pois deve incluir informações relativas a estrutura do empreendimento, tipo de impacto no solo, dentre outras questões de engenharia, além de informar brevemente se há bens culturais registrados em âmbito federal ${ }^{7}$ na área a ser pesquisada. Entretanto, é a partir dessa FCA que o(a) arqueólogo(a) do Iphan irá determinar em qual nível esse empreendimento se encaixa, e, consequentemente, quais serão as atividades necessárias para a obtenção da sua licença. Os níveis estipulados pela IN vão desde a categoria de "não se aplica”, na qual não há qualquer tipo de pesquisa arqueológica, até o "Nível IV", passando desde a entrega de um termo de compromisso do empreendedor (Nível I), monitoramento das obras (Nível II), até prospecções intensivas (Nível III) e atividades de educação patrimonial (quando há patrimônio arqueológico na área), dentre outras ações. A indicação do nível segue, em parte, o anexo II da IN 01/15, o qual arrola diferentes tipos de empreendimentos e em qual nível ele se encaixaria - embora essa lista não seja exaustiva e nem definitiva, como bem colocado no texto da instrução. Os(as) técnicos(as) possuem, assim, uma certa liberdade para irem além das indicações desse documento, por exemplo, pesquisando mais a fundo certas áreas e partindo de pressupostos científicos e não estritamente burocráticos para a definição dos níveis. Diego relata esse caso da FCA:

É, a gente usa dessa liberdade às vezes pra suprir algumas questões que a IN pode ser problemática. Só pra citar um exemplo de um empreendimento que, na nossa avaliação pela IN, se a gente fosse seguir estritamente a IN, ele seria classificado como nível I, ou seja, ele mandaria apenas um termo de compromisso assinado pelo empreendedor dizendo que se ele encontrasse um sítio ele notificaria o Iphan, mas na avaliação técnica nós vimos que era uma área de potencial e classificamos como nível III. O resultado disso foram sete sítios arqueológicos identificados, 
que se nós tivéssemos deixado a classificação tal como a IN sugere, nível I, bom... o empreendedor ia apresentar o termo de compromisso do empreendedor, ok, mas ele identificaria esses sete sítios no processo de construção? Dificilmente, até porque eram sítios com material lítico, sítios de superfície, onde esse material passaria batido no meio de uma área onde você tem afloramentos rochosos (...) então a gente tenta, na medida do possível, usar essa liberdade que a IN dá pra tentar suprir algumas deficiências que a gente acredita que ela também tenha.

Vale apontar que vários dos processos analisados possuíam uma temporalidade alongada, ou seja, do seu início até a anuência ou não do Iphan, duravam alguns anos. Isso causa ou a mudança do(a) arqueólogo(a) coordenador(a) do projeto e/ou da equipe, ou até mesmo dos(as) técnicos(as) analistas da SE/Iphan-RS. Os arqueólogos que atuam no setor de arqueologia do Iphan são, em sua grande maioria, funcionários temporários ${ }^{8}$. Sendo assim, sua identidade enquanto burocrata, atuando diretamente de dentro do aparelho estatal, é provisória. Com a troca dos(as) técni$\cos (\mathrm{as})$, há uma modificação nas interpretações e pareceres, devido, principalmente, à formação acadêmica e a experiência desses outros agentes. Técnicos diferentes podem, inclusive, questionar certas demandas apresentadas em pareceres anteriores. Todavia, isso não se dá apenas em processos de longa duração: em alguns casos que surgiram na pesquisa foram mais de quatro técnicos(as) diferentes analisando o mesmo processo em um período de tempo de um ano.

Esses são alguns dos meandros pelos quais os(as) arqueólogos(as) da SE/Iphan-RS passam na análise e tomada de decisões acerca de projetos e relatórios técnicos de arqueologia para o licenciamento ambiental. Deve-se entender também como esses documentos são confeccionados pelas equipes de arqueologia que trabalham em processos de licenciamento para empreendimentos. Ao ser perguntado sobre a relação entre produção de conhecimento científico e os relatórios finais, Joaquim virou a pergunta para mim mesmo, perguntando se eu acreditava que esses documentos eram onde o conhecimento arqueológico era exposto. Para esse arqueólogo, esses relatórios não cumprem o papel de construir um conhecimento científico interpretativo, e talvez nem devessem ter essa obrigação, pois o máximo que se pode fazer através deles é arrolar dados:

(...) às vezes os relatórios não dão [conta], não fazem ligações que a gente sabe, que a gente tem conhecimento, porque muitas vezes os relatórios estão ligados à empreendimentos bem pontuais e a gente fica restrito ali. (...) Geralmente $\mathrm{o}$ relatório ele morre ali [com a anuência do Iphan]. Eu penso que o relatório é o 
elemento, é o registro de tudo que a gente fez. Então esse item, que é o item da intepretação dos dados, ou da análise dos dados obtidos, porque se a gente só jogar dados ali nós que temos as melhores condições de interpretá-los, porque nós somos a equipe que tá lá, e afinal de contas, nós que produzimos os dados também. Então, eu penso que os relatórios que a gente produz eles são possibilidades de alguém pegar "agora eu quero falar sobre determinada coisa, eu posso usar o relatório como base" (...) Mas, se restringe a isso.

Para se pensar e entender essa relação entre apresentação, construção e interpretação de dados arqueológicos nesses documentos, e por quais constrangimentos e possibilidades eles passam, deve-se descrever o modo como eles são confeccionados. Tal questão perpassa desde as relações estipuladas entre a equipe de campo e a empresa de arqueologia, até o tipo de empreendimento e o porte da empresa de arqueologia (se é uma empresa menor com poucos projetos, ou se é uma maior, de âmbito nacional, e que atua em empreendimentos de grande porte). Esses fatores influenciam desde a definição do método de campo, até o tipo de análise e como e por quem o relatório final será redigido. Em alguns casos, por exemplo, o método de campo é apenas repassado pelos(as) coordenadores(as) do projeto para a equipe de campo, sem uma discussão maior com ela - os relatos dessas experiências geralmente são com empresas maiores e em trabalhos de grande porte. Douglas, arqueólogo graduado em arqueologia, relata que nesses casos ele apenas "recebia a metodologia pronta das empresas e ia a campo apenas para executá-la”. Após o campo, os dados, informações e fotos eram repassados para o arqueólogo coordenador do projeto redigir o relatório. Luísa, arqueóloga que atualmente é dona de uma empresa que atua principalmente fora do Rio Grande do Sul, mas que já esteve em situações desse tipo, define esse sistema como fordista, pois cada arqueólogo(a) e cada equipe de arqueologia - seja de campo, de laboratório ou de educação patrimonial - fica responsável por apenas uma parte do trabalho e não tem acesso ao produto final.

Então a gente já era muito mandado a fazer certos tipos de tarefas. Eu acredito que o produto tenha ficado satisfatório, mas para nós enquanto arqueólogos é um pouco frustrante, porque a gente não compõe o processo todo. Então é uma equipe que vai fazer educação patrimonial, é uma equipe que fala com as pessoas, é uma equipe que faz a produção do relatório. Você tem uma tarefa específica dentro desse mercado, então você vai, lá faz aquela sua tarefa específica, produz, entrega aquele [produto], e só fica responsável por uma parcela que alguém vai juntar tudo. 
Para um arqueólogo, na minha visão, isso é um pouco frustrante, porque parece que a gente não está produzindo o conhecimento em si. A gente tá produzindo uma parcela que alguém vai costurar.

Em outras experiências relatadas por arqueólogos(as), essa troca entre equipe de campo e coordenador ocorria, seja via uma reunião ou algum tipo de workshop, ou então - principalmente, quando são empresas de arqueologia de pequeno ou médio porte - inclusive durante o trabalho de campo, pois o coordenador do projeto acompanhava sua totalidade. Nesses casos há, muitas vezes, uma equipe fixa e com número reduzido de profissionais, o que facilita o contato e uma confecção mais colaborativa do relatório.

A grande maioria das empresas de arqueologia possui certa sistematização sobre como deve ser o registro em campo, possuindo desde modelos de diários de campo, até de coleta de dados, fichas das intervenções efetuas e tipos de fotos que os(as) arqueólogos(as) de campo devem seguir, os quais se baseiam geralmente nos requisitos das leis, portarias e instruções que regem a prática arqueológica - mas, também, nos pressupostos teóricos e metodológicos dos coordenadores do projeto e donos da empresa. Embora esses modelos de coleta de dados sejam positivos para uma certa homogeneidade do registro, facilitando a interpretação e organização posterior, alguns arqueólogos veem em muitos desses casos um constrangimento metodológico e teórico nesses requisitos. Esse é o caso de Rodrigo, professor universitário que atuou durante anos em empresas de maio expressão e afirma:

Como eu escuto muitas vezes falar de algumas empresas de arqueologia por aí que são muito rígidas (...) é tudo com fichas de cadastro de sítio já estabelecidas, vai fazer um desenho de estratigrafia já tem as cores estabelecidas, sabe? Não dá muita margem para que a criatividade no campo, para a percepção de coisas que não tão no protocolo. Então acaba que a tua cabeça fica voltada para preencher o formulário quando deveria ser o contrário, né: um formulário preenchido a partir do que tu está vendo e com uma certa liberdade metodológica.

O mesmo ocorre na confecção dos relatórios finais de campo. Angyone, arqueólogo que participou como arqueólogo de campo em empreendimentos de grande porte, relata como se dava a sistematização dos dados em campo para o relatório final:

Era um grande relatório, no final do campo, e relatórios diários. Eu, como coordenador de campo, tinha que emitir relatórios diários. Era um e-mail. Neste e-mail 
eu tinha que dizer: quantos poços-testes eu fiz, qual a coordenada e quais as fotos correspondentes neste e-mail. Isso era barbada de fazer, mas diariamente eu tinha que mandar este e-mail, que chegava lá no centro de geoprocessamento, e eles faziam tudo aquilo direitinho, né? Eu não precisava processar nada em campo, eu só mandava o dado. Mas era diário. O relatório diário, com poço-teste, a coordenada e a foto correspondente. Aí no relatório final, quando terminava o campo, aí eu tinha que mandar todas essas informações já computadas. Ficava bem mais fácil porque eu já tinha tudo pronto.

Paula, que atua como arqueóloga em uma empresa de arqueologia, relata que o processo de construção de um modelo de relatório passa tanto pelo envio de diferentes relatórios para o Iphan - e a constante (re)adequação do que é solicitado - quanto pela consulta a relatórios no setor de arquivo desse instituto. O objetivo de ter um modelo de relatório é que os mesmos não tenham pedidos de complementação, ou que tenham poucos. Os relatórios possuem, assim, um formato no qual o(a) arqueólogo(a) deve apenas adicionar ou subtrair informações: "Vai ter a apresentação do empreendimento, vai ter a localização do empreendimento, tu vai falar um pouco do histórico da região, de pesquisas arqueológicas na região ou no estado. Tu vai do macro pro micro até que tu vai chegar realmente nos dados que tu produziu". Alguns(mas) dos(as) interlocutores(as) relataram como esses modelos acabam interferindo nos seus próprios estilos de escrita, deixando-os cada vez mais técnicos, exatamente devido a essa repetição e às exigências da legislação. Era exatamente sobre essas questões que Joaquim se relatava ao definir a prática arqueológica no licenciamento ambiental como burocrática - como uma repetição de modelos prontos e um cuidado em seguir uma lista de itens definidos pela legislação -, se opondo à prática científica:

Existe uma coisa que é assim, se tu por incompetência, por falta de formação, por não ter os olhos atentos pra isso, tu não viu o negócio [sítio arqueológico], aquilo vai ser destruído. Eu tenho certeza que muita coisa foi e está sendo destruída, e muita coisa se perdeu, não por picaretagem ou malícia do arqueólogo de facilitar a sua vida, mas porque às vezes ele acha que no final até fez um ótimo trabalho, mas não se deu conta de várias coisas. E se ele não se deu conta, ninguém mais se deu conta, e o Iphan não vai se dar conta. Se tu faz um mau trabalho na arqueologia não é o Iphan, o Iphan não aponta quem faz maus trabalhos, ele aponta que faz maus relatórios. Às vezes tu pode fazer um excelente trabalho, mas teu relatório pode ser fraco, pode ser ruim. Ele [Iphan] vai te criticar o relatório. 
Os(as) arqueólogos(as) que atuam no licenciamento ambiental são, ou pelo menos se veem assim, em parte, cientistas e, em parte, burocratas, conhecendo os trâmites, documentos e tipos de discurso necessários para o andamento e anuência das pesquisas. Enquanto isso, os técnicos do setor de arqueologia do Iphan são, em primeiro lugar, burocratas, por terem que seguir mais à risca o andamento dos processos e a interpretação da legislação, mas também cientistas analisando o discurso e a interpretação de outros(as) arqueólogos(as). Todavia, a etnografia demonstrou que esses papéis de arqueólogo(a) e burocrata são muito mais fluídos do que aparentam ser.

Do mesmo modo que com os técnicos do setor de arqueologia da SE/Iphan-RS, os(as) arqueólogos(as) que vão a campo e confeccionam esses relatórios tem visões diferentes deles e procuram possibilidades e maleabilidades no processo de construção. Francisco, arqueólogo free-lancer, vê nesses documentos a possibilidade de não apenas apresentar uma interpretação mais aprofundada, mas também de criar uma arena de diálogo com o Iphan no que tange a recomendações sobre a proteção de certas áreas ou sítios arqueológicos: "eu acho que o momento da confecção do relatório é o teu momento de expor e de opinar sobre várias questões. Acho que tu cumpre com aquele ritual ali exigido pelo Iphan de tais itens, mas tu vai ter o teu espaço de opinião e até de preservação de algumas áreas”. Contudo, como expõe Bento, também um arqueólogo sem empresa própria, isso varia entre cada arqueólogo(a), seu comprometimento ético e até de tempo para produção desses relatórios:

Aí depende do profissional, do comprometimento do profissional com a atividade. Tem profissionais que vão se ater ao básico, fazer aquele trabalho burocrático, fazer os relatórios, fazer as planilhas lá, “tá, o que o Iphan pede tá bom, tá entregue”. E tem outros que vão se preocupar, sabe, vão se preocupar e fazer uma coisa com maior qualidade, envolver a comunidade, sabe, se aprofundar na questão científica.

Todavia, tanto para os arqueólogos quanto para os técnicos da SE/Iphan-RS, esses relatórios são vistos em sua grande maioria como repetitivos, engessados e constrangidos por diferentes fatores. Na minha pesquisa com esses documentos encontrei diversos relatórios que atendiam apenas o mínimo do requisitado pela legislação e com interpretações, conclusões e apresentação dos resultados muito difusas, breves e rasas. Claro que há também exemplos de relatórios extremamente bem feitos e construídos, com atividades, levantamentos e pesquisas que vão muito além do mínimo exigido por lei. O principal apontamento dos(as) técnicos(as) da 
SE/Iphan-RS, relatado também nos pareceres, acerca dos problemas desses relatórios e da demora para a anuência dos mesmos é a discrepância no que eles apresentam como método de pesquisa, as atividades feitas e os resultados obtidos. Muitas vezes falta uma revisão desses documentos: deixa-se de anexar algum mapa, de descrever todas as intervenções feitas, mas também pode haver uma falta de clareza no texto, tanto na questão da gramática quanto nas conceituações teóricas da ciência arqueológica no que tange à justificativa de algum método ou interpretação. Diego define assim os relatórios que eles têm recebido na SE/Iphan-RS:

(...) cada vez mais o que a gente recebe é uma receita de bolo. Cada vez mais o que a gente tem são relatórios feitos para atender a legislação, e não relatórios para gerar bons resultados de pesquisa. São raros, diga-se de passagem, são bastante raros os relatórios que a gente diga "olha, esse aqui é um bom trabalho de pesquisa”. O que a gente tem são relatórios que atendem a legislação. E muitos não atendem.

Os constrangimentos burocráticos vindos do Iphan ou os científicos vindos das próprias empresas de arqueologia tomam conta muitas vezes da prática arqueológica no licenciamento ambiental, devido também à pressão dos empreendedores para uma anuência rápida e sem problemas. Nesse contexto, há críticas por parte dos(as) arqueólogos(as), por às vezes terem que seguir modelos pré-prontos e por não conseguirem desenvolver maiores interpretações e resultados devido a prazos e orçamentos, e críticas por parte dos(as) técnicos(as) do Iphan, por receberem na maioria das vezes relatórios que são meras "receitas de bolo". Nesse contexto, entra também a questão dos orçamentos e prazos, os quais definem muitas vezes as possibilidades metodológicas e teóricas dos trabalhos de arqueologia. Embora não citado nas entrevistas, mas conversado e debatido em outros espaços, o embate entre propostas orçamentárias de diferentes empresas de arqueologia gera um ambiente no qual o menor preço fica com o trabalho, entretanto, isso acaba inviabilizando, muitas vezes, uma pesquisa mais densa e profunda. Todas essas disputas e constrangimentos infligem diretamente no trabalho de campo e de laboratório das equipes de arqueologia, na confecção dos relatórios e da sua análise pelo corpo técnico do Iphan, e na identificação, registro e salvaguarda do patrimônio cultural.

Analisando diversos artigos, dissertações e teses de arqueologia, Reis (2010) demonstrou como a teoria arqueológica fica implícita neles. O posicionamento conceitual dos(as) autores(as) não é exposto de forma clara, mas sim ao longo do texto 
e, principalmente, na análise dos dados. Isso também se repetiu na grande maioria dos relatórios e projetos analisados. A seção específica de teoria às vezes não passava de uma página, enquanto o foco maior residia na parte da descrição do método de intervenção. Esses relatórios, em muitos casos, tanto nos que analisei quanto no que os técnicos do setor de arqueologia da SE/Iphan-RS trouxeram na entrevista, são documentos que não adentram na interpretação dos dados e, consequentemente, na construção de considerações acerca do potencial arqueológico da área, sobre patrimônio cultural e o que deve ser feito para resguardá-lo. Embora alguns trabalhos no licenciamento acabem gerando pesquisas acadêmicas ${ }^{9}$, muitas das informações e dados sobre sítios arqueológicos encontrados nesses projetos ficam retidos nos arquivos das SEs do Iphan. Os interlocutores apontaram a falta de tempo para preparar publicações a respeito dos resultados, devido à grande demanda de trabalho que impede que os(as) arqueólogos(as) se foquem na interpretação dos dados para além daquilo necessário para os relatórios finais.

A pergunta imposta pela legislação, e pelas pressões políticas e econômicas dos empreendedores, gira apenas em torno da averiguação de se há ou não cultura material arqueológica (artefatos e/ou sítios) na área. Cabe ressaltar que esses constrangimentos não afetam apenas as práticas e análises dos arqueólogos que trabalham em projetos de licenciamento ambiental, mas também o próprio corpo técnico da SE/ Iphan-RS. Esses arqueólogos veem as suas possibilidades de ações políticas, sociais e até no que tange a uma liberdade teórico-metodológica e científica nesse instituto, em relação à análise de processos de licenciamento, de forma "pessimista”. Isso se dá devido ao cargo que assumem e suas responsabilidades, direitos e poderes frente à legislação e às pressões internas e externas, como relata Diego:

Então a gente está, nós enquanto técnicos, por exemplo, colocados entre o empreendedor que quer construir, a comunidade para a qual a gente deveria estar, supostamente, dirigindo os nossos esforços, mas que está descolada disso, e que a gente não consegue dialogar de fato com ela... o interesse do próprio estado de construir uma narrativa que legitime a sua posição, a sua situação, etc. A gente está amarrado por uma série de burocracias, a gente não tem braços pra estar produzindo conhecimento. Eu acho que esse é o grande problema, a nossa falta de possibilidade de pró-ação, o Iphan é um órgão extremamente, hoje pelo menos, eu não posso falar de antes, mas a realidade que a gente vive hoje é de um órgão passivo que recebe demandas e reage a elas dentro das suas limitações, que são várias. Uma das críticas que a gente ouve constantemente é isso, o Iphan, as pessoas aqui dentro do Iphan 
não têm projetos. A gente não consegue fazer as coisas pelo patrimônio, apenas receber relatórios e reagir a eles, receber projetos e reagir a eles, receber denúncias e reagir a elas. Então eu acho que todos nós aqui gostaríamos de um Iphan muito diferente do que ele é e nós gostaríamos de sim, estar fazendo arqueologia, estar entendendo melhor como esses sítios estão ou não estão ou podem estar em diálogo com as pessoas que estão ali ao redor, estão ali em cima, mas na verdade a gente não faz isso, até esse momento não conseguimos fazer.

Os trabalhos de arqueologia no licenciamento ambiental, e, consequentemente, a confecção de relatórios técnicos que descrevem e analisam as atividades e os dados obtidos, tentam se equilibrar em um duplo papel: entre científico e burocrático. Roberta, dona de uma empresa de arqueologia, nota duas coisas importantes ao redigir relatórios: uma, é ela como arqueóloga e cientista mais preocupada com interpretações e análises; e outra, é ela como arqueóloga contratada que deve responder ao Iphan a partir das normas e demandas. Para ela, isso leva em consideração não apenas o modo como se faz arqueologia, e como ela pensa arqueologia, mas a possibilidade de que novas pesquisas aproveitem esses relatórios:

(...) tu tá criando um contexto com outros sítios, com a história que tu sabe, com as etnias que ocuparam aquela região. Isso é o que precisa ser dito, porque é sobre isso que a gente fala. Aquele material está contando uma história. E essa história é o contexto. Então, do ponto de vista do trabalho que eu gosto de fazer é isso. Outra coisa é os dados pro Iphan, eu tenho que garantir que os dados estão ali. Todos eles: 100\% do registro fotográfico, 100\% do registro tem que ir, 100\% do registro tem que ir organizado, 100\% do registro tem que ir georreferenciado, $100 \%$ do registro tem que ir com a descrição do sedimento. Porque essas são informações que eu posso achar irrelevantes, mas no futuro alguém vai ter um problema de pesquisa em que aquele dado possa ser relevante. Então, a minha responsabilidade é dar o máximo de informação possível. Então, é isso. Apresentar os dados, amarrados com a metodologia que eles aprovaram, e dar o contexto.

Sendo o licenciamento ambiental uma ferramenta de controle e ocupação territorial, atrelada a uma ideologia de progresso econômico, as práticas científicas emaranhadas nessa rede entram em uma arena de disputas, na qual os dados provenientes das análises são utilizados pelos mecanismos de poder para fomentar um discurso empresarial e desenvolvimentista. O objetivo final dessas legislações e práticas estatais, burocráticas e empresariais é justificar, através de um controle sobre os estudos e discursos disciplinares, a "localização dos empreendimentos e a sua 
ocupação territorial, defendendo o desenvolvimento como meta e determinando estratégias para construção dos aparatos de controle e gestão dos territórios e das populações” (Bronz, 2013:41). Dentro desse contexto, a principal problemática citada pelos(as) arqueólogos(as) entrevistados no que se refere ao entendimento dos processos burocráticos do licenciamento e da abertura de possibilidades dentro deles foi o domínio de uma linguagem mais técnica e da legislação que a maioria dos(as) arqueólogos(as) não possui. Esse problema com a legislação foi citado por diversos(as) interlocutores(as) que sentem falta de um entendimento mais profundo das leis, normativas e portarias que regem as práticas arqueológicas, seja devido ao linguajar utilizado, aos trâmites e análises não homogêneas do Iphan, ou até a sua formação acadêmica, que não possui nenhum foco nesse tipo de questão. Entretanto, Joaquim aponta para outro entrave em relação ao embate entre esses diferentes discursos no que tange à análise dos arqueólogos(as) que trabalham na SE/Iphan-RS:

Eu já vi muitas leituras superficiais dos trabalhos, e muitas vezes, não vou dizer muitas, estou exagerando. Algumas vezes eu tive que dialogar com o Iphan muito mais pra esclarecer o que eles não tinham entendido, o que pra mim estava claro nos relatórios, do que propriamente pra rebater alguma coisa. Então, eu acho que pela dinâmica, acho muito lamentável que a gente não tenha concurso pra funcionários efetivos do Iphan, e que tenha concurso pra pessoas que ficam dois, três anos lá e depois saem fora. Isso não cria maturidade no corpo técnico do Iphan, que não tem uma bagagem pra ir servindo de exemplo no que dá certo e no que não dá ou como proceder nas coisas. Então, as minhas maiores dificuldades de comunicação com o Iphan muitas vezes são mais nesse sentido, que há uma leitura equivocada no que está se colocando. E aí isso gera uma burocracia louca, um monte de ofícios e tal, mas por um problema... que é, assim, ele está à margem da questão arqueológica propriamente dita.

Contrariando a última frase do depoimento de Joaquim, o que mostrei ao longo destas últimas páginas é que a burocracia estatal não está além ou à margem da questão científica arqueológica. Ambas estão sendo coproduzidas nessa rede, não há uma divisão entre fazer ciência e fazer política, ainda mais no contexto do licenciamento ambiental. Claro que há assimetrias de poder e de agência, mas a rede que emaranha a prática arqueológica nesse contexto não pode ser entendida a partir de uma divisão entre ciência e política. A trilha de documentos, de projetos, relatórios, 
ofícios e pareceres, não é apenas um canal de comunicação, de troca de informações, entre as partes, mas é também mediadora na constituição de diferentes práticas e entidades. O produto dessas práticas e, principalmente, dos relatórios, não é apenas dados arqueológicos, mas sim a constante constituição dessa ciência, do estado, da burocracia e do patrimônio.

\section{Patrimônio como caixa-preta}

Entremeada nessas disputas, coproduções e constrangimentos está a fabricação de uma entidade chave para a arqueologia, fora ou dentro do licenciamento ambiental: o patrimônio arqueológico. Durante minha pesquisa, uma das linhas de análise foi pensar o patrimônio como uma caixa-preta, no sentido latouriano, ou seja, como um instrumento de simplificação e ocultamento de incertezas, controvérsias, concorrências e do próprio trabalho de construção de um fato científico (Latour, 2011:6). Tal questão surgiu, pois ao analisar a legislação que trata da definição de patrimônio arqueológico, e debater com os(as) arqueólogos(as) entrevistados(as) sobre como eles definem o que é patrimônio, e, principalmente, um sítio arqueológico, notei que havia dois conceitos diferentes sobre a mesma entidade que nem sempre conversam entre si. Patrimônio é, por um lado, um conceito jurídico e burocrático, constituído por diferentes legislações, documentos e trâmites, e, por outro, um conceito êmico da ciência arqueológica, construído pelos(as) arqueólogos(as) através de suas formações, posições teóricas e experiências.

Em trabalhos anteriores (Wittmann, Baptista da Silva, 2017; Wittmann, 2018), apresentei mais especificamente as legislações, portarias e instruções normativas que regem e definem o que é ou não patrimônio arqueológico. Vou me atentar aqui a outro aspecto dessa discussão: como os trâmites burocráticos, alguns documentos específicos, pressões diversas e os próprios conceitos dos(as) arqueólogos(as), de dentro e de fora da SE/Iphan-RS, participam da disputa para fabricar patrimônio arqueológico para o estado. Apresentarei também, de forma sucinta, a relação e o papel das comunidades do entorno de projetos de empreendimentos e de "não-arqueólogos" nas equipes de campo nesse debate. Essas questões influenciam na produção do conhecimento científico, elas constrangem e/ou abrem novas perspectivas de análise e interpretação.

Ao mesmo tempo em que o licenciamento ambiental é uma arena de espetacularização de conflitos sociais e ambientais, esses devem ser domesticados, no sentido de se conhecerem os agentes envolvidos e impor a eles racionalidades e normativas 
estatais e empresariais (Bronz, Fraiman, 2009). Nesse âmbito, o registro arqueológico, da forma como é regulamentado e praticado nesse contexto, funciona como uma ferramenta que oculta e cala muitos desses conflitos e os agentes envolvidos. Contudo, tal fenômeno não é particular da prática arqueológica feita no licenciamento ambiental, mas sim, uma construção sócio-histórica dessa ciência.

A conexão entre arqueologia e estado, principalmente no que tange à construção de uma narrativa histórica e uma memória coletiva acerca dele, data desde o início da concepção dessa ciência. No Brasil Imperial, por exemplo, deu-se início à construção de museus para abrigar artefatos que simbolizavam a política mnemônica do país, abrangendo desde os tempos pré-coloniais até a atualidade (Ferreira, 2010). Na década de 1960, com o início da profissionalização e institucionalização da arqueologia, o conhecimento e objetivo dessa ciência eram principalmente o de identificação e registro de sítios arqueológicos no território nacional (Bueno, 2011), a fim de se criar um mapa de dispersão de culturas arqueológicas pré-coloniais e do potencial de pesquisa por região. O paradigma científico seguido pela arqueologia de então, voltada para o histórico-culturalismo e uma divisão entre um passado pré-histórico - povoado por grupos indígenas não mais existentes - e uma história atual, foi consolidado juridicamente pela Lei 3.924 de 1961, conhecida como Lei de Arqueologia. Essa ciência, desde então, não se afastou completamente desse objetivo de mapear, identificar e registrar o patrimônio cultural nacional, nem desse paradigma acerca das populações indígenas ${ }^{10}$, seja no que tange à prática acadêmica ou ao licenciamento ambiental.

Um exemplo disso é o modo como são apresentadas nos projetos e relatórios para o licenciamento as narrativas acerca das populações indígenas. Em cada projeto há uma contextualização histórica e arqueológica da região pesquisada, as quais geralmente são divididas entre uma narrativa com seu foco na história do período colonial e da colonização europeia mais tardia - apresentada de modo positivista, com datas e fatos -, e uma descrição dos dados arqueológicos - na grande maioria das vezes, apenas dos tipos de sítios e de materiais arqueológicos registrados para a região. Em poucos processos analisados havia uma seção para algum tipo de história indígena, ou etno-história (com o foco no protagonismo e papel dos povos indígenas na história da região ou do estado). Repetindo a estrutura narrativa de muitos trabalhos acadêmicos de arqueologia, esses projetos e relatórios têm uma divisão clara entre o que pertence a uma história de formação política, social, cultural e identitária do estado e/ou da população, e o que pertence à arqueologia: o passado 
distante e desconexo do presente ${ }^{11}$. Tal distanciamento dessas outras narrativas, as quais trazem também outras cosmologias, limita outras visões e entendimentos de patrimônio, paisagens, ambiente e de impacto a esses locais e coisas.

Deve-se pensar a definição de patrimônio não como algo técnico, definido simplesmente por certas categorias, importância e valores, mas como parte do projeto de formação de um estado-nação. Desta forma, o registro arqueológico - ferramenta de identificação e de controle do que é ou não patrimônio - age diretamente no ocultamento de conflitos e do papel das comunidades no debate acerca do que é representativo para a história e memória de um certo grupo social ou de uma nação. A forma como esse registro é concebido e colocado em prática não é apenas fruto de um debate teórico, por exemplo, entre processualistas e pós-processualistas (Pellini, 2014), mas também - e principalmente no licenciamento ambiental - origina-se e constitui-se materialmente em documentos e trâmites burocráticos (os quais possuem intrinsicamente teorias e métodos arqueológicos). Tal questão me ficou clara ao analisar os processos na SE/Iphan-RS e ao conversar com os técnicos sobre como é o processo de registro de sítios arqueológicos. Nessa rede de constituição do patrimônio arqueológico, não são apenas os argumentos, justificativas e dados científicos sobre determinado sítio arqueológico que participam na sua materialização legal como tal, mas também, e em alguns casos principalmente, documentos burocráticos, as próprias concepções dos(as) arqueólogos(as) da SE/ Iphan-RS que analisam essa documentação, interesses do estado e restrições de orçamento e prazos para a pesquisa. Paulo, arqueólogo da SE/Iphan-RS, expôs algumas das questões e constrangimentos que abarcam a definição de sítio arqueológico pelo Iphan, principalmente no que se refere aos interesses do estado e os limites da legislação:

(...) um exemplo, se registra um sítio com a dimensão gigantesca, então, bom, realmente é tudo isso? Se é tudo isso, então toda aquela área ali nada mais vai poder ser feito sem ter um acompanhamento arqueológico junto, qualquer intervenção ali pode resultar posteriormente em um crime ambiental, porque eu vou estar dizendo que é um sítio arqueológico, etc. Isso é um aspecto que a gente tem legislações que nos amparam, mas em muitos casos elas também nos deixam incertos, porque, por exemplo, a Lei de Arqueologia de 61 ela é muito clara em relação aos sítios pré-coloniais, mas deixa muitas brechas com relação aos sítios históricos. Então na nossa análise a gente acaba tendo sempre que ponderar os desdobramentos de cada decisão que a gente toma, ou seja, se há um sítio em um 
lugar esse sítio passa a ser responsabilidade do Iphan eternamente, seja se ele for preservado in situ, se ele gerar um acervo que vai continuar sendo bem da União e que não vai poder ser descartado. (...) nós somos constantemente monitorados e cobrados pelo Ministério Público do Estado, Ministério Público Federal, principalmente, que atua no direito difuso e que é o responsável por garantir as questões, por exemplo, do meio ambiente, do patrimônio. Então existem muitos desdobramentos no momento que eu digo que algo é um sítio arqueológico. Os desdobramentos disso são enormes, então a gente acaba tendo que sempre ponderar em relação a algo que está na nossa frente, o que vai acontecer, não se trata de simplesmente fazer um parecer e assinar e aquele problema está resolvido. Nós criamos um passivo que vai ter que ser acompanhado eternamente.

Contudo, não é apenas após o trabalho de campo que esses constrangimentos e questões influenciam na definição ou não de um patrimônio arqueológico. Obviamente, prazos e orçamentos implicam na qualidade e potencial da pesquisa efetuada, pois nem sempre as equipes de arqueologia têm a possibilidade de efetuarem certas atividades e possuírem um tempo maior para as análises. Outro fator que influi nessa questão é o próprio tipo de empreendimento, já que este afeta o método da pesquisa arqueológica, o qual, consequentemente, afeta na identificação de sítios arqueológicos. Francisco exemplifica essa questão através de sua experiência em projetos de licenciamento na malha urbana de cidades:

Vai depender do estado de conservação do local, vai depender do tipo de empreendimento que está sendo feito ali, e basicamente no meu ver, em que estado de conservação que vai estar o local. Porque daqui a pouco tu vai ter material arqueológico, mas não vai configurar um sítio arqueológico. Isso aconteceu em alguns lugares, por exemplo, nós trabalhamos no acompanhamento de uma obra de gás, instalação de gás natural em um bairro de Porto Alegre, e como ela era feita com essas sondas perfuratriz, então, por exemplo, numa quadra tinham só duas aberturas, uma em cada esquina. E às vezes saía material e a gente coletava. Só que fica muito difícil tu afirmar que aquilo é um sítio. Como tu está trabalhando em uma área de rua, que foi várias vezes impactada, tu não tem toda a rua aberta, tu não tem uma vala pra tu ver a estratigrafia, tu tem algumas janelas só. Então tu tem material arqueológico, mas é muito complicado tu afirmar que tu está em um sítio arqueológico. Pelo potencial do bairro, pelo histórico do bairro que tu fez previamente, pelo projeto, tu vê que tu está numa área de potencial alto. Isso é evidente. Mas tem que ter muito cuidado. 
A ficha de registro de sítio arqueológico, regulamentada em 1998, é o documento que aponta as características que devem ser preenchidas e identificadas a fim de serem legíveis para o estado cadastrar algo como um patrimônio arqueológico. A ficha também é o documento de análise principal dos(as) técnicos(as) do Iphan para aceitarem ou não o registro de um sítio. Contudo, estão emaranhadas nesse documento certas teorias e métodos específicos. Por exemplo, as características culturais acerca dos artefatos encontrados são meramente de caráter material, morfológico e funcional, excluindo a ligação entre os vestígios arqueológicos e as populações indígenas, e entendimentos e interpretações outras para esses objetos e locais. O mesmo se dá na definição da importância, relevância e excepcionalidade do sítio. Isso é definido através de gradações e cálculos que levem em conta o estado de conservação do sítio - ou seja, quanto mais preservado, mais importante e relevante -, potencial científico - definido pela presença de um certo tipo de cultura material específica e cronologia avançada -, e por último a importância que a comunidade do entorno dá ao local - o que nem sempre é levado em conta e/ou registrado. Além desses constrangimentos de ordem burocrática, legal e estatal e de concepções teóricas previamente definidas na ficha de registro, a análise e aceite dela passa por outras questões de cunho estrutural e hierárquico do Iphan, como relatado por Paulo:

O cadastro, ele tem que ser a ficha apresentada, e a ficha tem que ser homologada aqui por nós, até pra ponderar essas questões, se é sítio histórico tem que passar por todas essas ponderações, porque não tem uma questão clara na legislação sobre isso e tal. E com base nisso a gente encaminha as fichas pra Brasília [CNA], que daí Brasília que sobe isso pros bancos de dados do Iphan. Então na verdade passa pela nossa avaliação e às vezes chega lá, por exemplo, já aconteceu de chegar no Centro Nacional de Arqueologia e o Centro Nacional de Arqueologia não concordar e mandar de volta pedindo esclarecimentos sobre tal sítio, por exemplo. "Isso é de fato um sítio arqueológico?” Porque a gente não identificou nas informações tal coisa e tal coisa. Então, até mesmo bater os dados de pontos [de UTM, georreferenciados] que foram apresentados nas fichas a gente tem que fazer, porque às vezes um errinho de digitação... a gente não tem como mexer na ficha, porque a ficha que vai pra Brasília é a ficha original assinada pelo arqueólogo. (...) E mesmo $o$ arquivo digital do acces ${ }^{12}$ a gente não tem como mexer, porque a gente não tem o acces nos nossos computadores. Então a gente não tem nem como corrigir as fichas digitais, que também são importantes pra mandar pra Brasília. Então, assim, qualquer erro que a gente identifique, porque a gente só consegue fazer a leitura 
das fichas, tanto a digital quanto a física, a gente tem que mandar para o arqueólogo de volta, pro arqueólogo mandar pra gente ela corrigida, pra gente poder mandar pra lá.

Se nos documentos e trâmites burocráticos aparecem esses constrangimentos, barreiras e limitações, nos discursos dos(as) arqueólogos(as) sobre seus trabalhos de campo, análises e interpretações sobre os sítios, materiais e paisagens, o panorama é outro. Enquanto nos primeiros os conflitos, diferentes discursos, demandas e significados não possuem espaço, nos relatos de experiências dos(as) interlocutores(as) há narrativas repletas e povoadas de pessoas, ideias, interpretações e demandas. Relatos sobre descobertas com moradores locais e com auxiliares de obra que trabalhavam no campo foram recorrentes nas entrevistas, assim como as interpretações, discursos e significados que essas pessoas construíam sobre o local ou sítio de pesquisa. Todavia, nos relatórios sobre as áreas pesquisadas, o campo arqueológico é povoado apenas pelo registro positivo ou negativo de uma cultura material muda e morta, geralmente reduzida a sua forma e função. Paulo, arqueólogo da SE/Iphan-RS, reflete sobre a relação entre sociedade, arqueologia e Iphan:

(...) em relação à sociedade eu acho o Iphan, não a arqueologia dentro do Iphan, mas o Iphan enquanto instituição de modo geral, uma instituição hipócrita. Usa no discurso a sociedade, mas na hora de trabalhar o patrimônio, está trabalhando o patrimônio desassociado dessa sociedade. Porque a maior parte dos bens tombados, valorados e registrados dentro do Iphan são escolhas de pessoas que estão dentro do Iphan, não são escolhas de pessoas, da sociedade que está chegando, "olha, a gente tem interesse nisso". Poucos são os casos que ocorreu o tombamento, registro de casos assim. Enfim, sítio arqueológico também. Sítio arqueológico eu também acho um tanto hipócrita, mas é uma hipocrisia dos próprios arqueólogos de modo geral, e isso me incluo também enquanto arqueólogo, porque os arqueólogos tendem a desassociar o patrimônio arqueológico da sociedade que detêm ele. Eu tenho sérias críticas ao funcionamento do Iphan hoje em dia, em relação principalmente a isso, de usar num discurso a sociedade e na hora de valorar as coisas que a sociedade podia estar pedindo pra valorar eles excluem do discurso e vira um discurso extremamente institucional e de escolha institucional.

O potencial arqueológico da área pesquisada, por exemplo, é definido, segundo o inciso II da IN 01/15, através da vistoria local (via caminhamentos e intervenções subsuperfície) e pelo "cruzamento de dados, do processo histórico de ocupa- 
ção, com a incidência de sítios cadastrados, indicadores geomorfológicos e demais modelos preditivos de avaliação", ou seja, ficam de fora da produção de conhecimento acerca do patrimônio cultural do local os conhecimentos, saberes e interpretações das comunidades atingidas ou do entorno. No que tange a populações indígenas e quilombolas, só ocorre uma consultoria para com estas quando o trajeto do empreendimento passar por alguma terra desses povos. Entretanto, a preocupação de inserir as falas, interpretações e demandas das comunidades do local da pesquisa apareceu nas falas de alguns(mas) dos(as) arqueólogos(as) entrevistados(as). Para Francisco, por exemplo, a definição de sítio arqueológico deve partir da possibilidade de contar uma história que importe para a população do entorno:

Eu acho que na verdade o sítio é aquilo que eu falei também, assim, tem material arqueológico e tem sítio arqueológico, é diferente. Pode ter material antigo que está ali extraviado e tu pode ter alguma coisa muito legal que tu pode contar alguma história. Aquilo pode ser importante pra alguém, e se é importante pra alguém é legal registrar. Se não é importante não tem sentido tu estar ali, não tem sentido também tu pegar. A gente também se pauta nesse tipo de coisa, tu tem que ter contexto, tem que ter um contexto. Tem que saber contar uma história com aquilo ali. Se não, não tem sentido nenhum tu recolher esse material, tu passar todo esse trabalho, todo esse método direitinho, por camadas e coisa e tal. Depois tu não vai saber nem contar uma história, "não, o material era antigo, eu fiz tudo que era necessário pra salvar o material”. Tá, mas e dai? Quem que morou aqui? Que que era esse lugar? Isso é importante pra quem? As pessoas ainda tão por aqui? Será que tem descendentes desses antigos moradores nessa região? Será que não seria legal se desse pra trazer esse pessoal aqui? Tu começa a refletir sobre a tua atuação em campo. Isso é legal quando tu consegue atingir, digamos assim, esse patamar de pesquisa que te possibilita linkar o teu trabalho com os moradores do local e os moradores mais antigos. E talvez tenha ainda descendentes na região.

Contudo, esse contato e essa relação com a comunidade dependem tanto do prazo e cronograma do trabalho, quanto da posição teórico-metodológica da pesquisa e da equipe envolvida no trabalho de campo. Geralmente, o contato com a comunidade é rápido e feito através de conversas informais ou entrevistas, com o intuito de coletar alguma informação histórica sobre o local, se há algum indício de sítio arqueológico, sobre coleções pessoais de peças arqueológicas, dentre outras questões. Isso depende muito também da área onde ocorrem os trabalhos e o tipo de empreendimento. Em áreas rurais, por exemplo, quando o trabalho é de curto 
prazo, o foco é nas intervenções subsuperfície na área a ser pesquisada e nos caminhamentos ao longo dela. Os dados empíricos, materiais, são vistos como mais importantes do que aqueles vindos da comunidade. Contudo, em alguns trabalhos no meio urbano há a possibilidade dos transeuntes abordarem os(as) arqueólogos(as) - muitas vezes por confundirem eles(as) com os(as) engenheiros(as) da obra por ambos(as) utilizarem capacetes brancos -, o que gera, segundo os relatos dos(as) interlocutores(as), um espaço muito profícuo de conversa, troca de informações e divulgação. Mesmo assim, na maioria das vezes o contato com a comunidade serve para a equipe de arqueologia como um método alternativo para a prospecção da área, não se criando laços de sociabilidade ou uma relação mais longa de pesquisa com essas pessoas - até porque os trabalhos de arqueologia no licenciamento ambiental são pontuais e os membros da equipe, quando não toda a equipe, transitam muito de um campo a outro, de uma região do Brasil para a outra. Rodrigo relata sua experiência com essa questão do contato e conversa com moradores em seus trabalhos no licenciamento ambiental:

Nos trabalhos de arqueologia de contrato eu nem contatei pessoas. Simplesmente ia lá, cavava os buracos, fazia relatório, escrevia o que tinha que escrever, quinze dias depois eu estava em casa. Então o contato, claro, que eu estou falando da minha etapa que era o trabalho de campo, depois tinha equipes de educação patrimonial que iam lá e aí sim faziam contato. Então o contato com as comunidades locais é uma ferramenta. Uma ferramenta, uma estratégia para você resolver algum problema relativo ao trabalho. Achar sítio ou ter acesso a uma área que as pessoas não estão tendo. Principal ferramenta é achar sítio, conversar com as pessoas da comunidade local "onde é que estão? Onde é que estão achando os caquinhos de cerâmica por aí?”. É uma ferramenta (...) é só uma ferramenta para potencializar a eficiência do método de mapeamento de sítios e prospecção. É um protocolo. É um contato protocolar, não tem objetivo de transformação de consciência sobre patrimônio, sobre as ocupações indígenas locais, por exemplo, sobre a história das pessoas que compõem aquela comunidade.

O depoimento de Rodrigo corrobora com a interpretação de Luísa sobre a divisão da produção de conhecimento arqueológico no licenciamento ambiental. No caso exposto acima, o arqueólogo é aquele que produz conhecimento e um discurso acerca do patrimônio cultural material através de suas teorias e metodologias, sem auxílio da comunidade do entorno. Comunidade essa que apenas é acionada em 
uma etapa posterior quando a equipe de educação patrimonial faz as atividades de divulgação e extroversão do conhecimento produzido. Essas ações educativas variam muito de formato e abrangência dependendo do tipo de empreendimento, do prazo e do orçamento, e são efetuadas na maioria das vezes nas escolas mais próxima da área do empreendimento. A educação patrimonial - sua conceituação, aplicação e objetivo - foi criticada por praticamente todos(as) os(as) interlocutores(as). O pouco tempo para as atividades, a falta de uma definição clara do que seria uma educação patrimonial na legislação, a falta de formação específica dos arqueólogos para coordenarem esse tipo de ação e o fato de entenderem que tais ações não deveriam ser realizadas pela equipe de arqueologia, mas sim por um museu ou até pelo Iphan, foram os pontos mais citados. Geralmente estas atividades de educação patrimonial se reduzem a palestras e oficinas informativas sobre a prática arqueológica, não sendo efetivamente uma ferramenta de divulgação do patrimônio e muito menos de construção conjunta deste com a comunidade. Essa crítica não é feita apenas pelos(as) arqueólogos(as) que participam dos projetos, mas também dos(as) arqueólogos(as) da SE/Iphan-RS, os quais também não tem muito espaço de manobra para requisitarem algo diferente. Entretanto, foram expostos exemplos de projetos em que, com um cronograma maior, as atividades efetuadas foram avaliadas como positivas e com um alcance bom para com a comunidade escolar ${ }^{13}$.

Um dos atores mais citados pelos(as) interlocutores(as) que se enquadra em um papel de "não-arqueólogo", mas que tem certa agência e influência na produção do conhecimento arqueológico e da constituição do patrimônio em campo, são os auxiliares de obra. Eles geralmente são cedidos pela empresa contratante ou contratados na cidade onde ocorrerá o empreendimento para realizarem os trabalhos mais pesados de abertura de área de mata, intervenções subsuperfície, peneiramento de sedimentos, dentre outras atividades. Deste modo, eles participam muitas vezes de toda a extensão do trabalho de campo, inclusive a descoberta de sítios e/ou de artefatos - aprendendo com os(as) arqueólogos(as), e também ensinando-os(as) a identificarem certas coisas. Vários(as) interlocutores(as) deram exemplos de auxiliares - muitas vezes moradores da região, pescadores ou agricultores - que sabiam identificar ossos de animais, fragmentos de cerâmica e peças líticas, e até escavar, por terem experiência em trabalhos anteriores, muitas vezes melhor que os(as) próprios(as) arqueólogos(as) da equipe. Esses exemplos mostram como esses outros atores, interpretações e conhecimentos, mesmo que ocultados no produto final, influenciam na construção do conhecimento arqueológico no licenciamento ambiental. 
Como dito acima, esses relatos, encontros e experiências dos(as) arqueólogos(as) em campo acabam não transparecendo, não tendo espaço nos textos dos relatórios finais, nem na interpretação dos dados arqueológicos e nem na análise dos técnicos da SE/Iphan-RS. Quando analisei os processos de licenciamento me deparei com quatro tipos de utilização e descrição das falas de moradores (quando havia): 1) a partir de pequenos questionários sobre a faixa etária, o tempo de moradia no local e se conhecia algum sítio arqueológico, era feita uma tabela com a quantificação desses dados; 2) citações de pequenas falas de moradores ao longo do texto sobre o conhecimento ou não de sítios ou materiais arqueológicos na área ou região; 3) entrevistas gravadas com moradores e com as transcrições inseridas como anexo nos relatórios, ou seja, fora do espaço mais formal de descrição dos dados e das interpretações; 4) um trabalho mais longo e denso com as pessoas que moravam na área ou no entorno dela, tanto de entrevistas quanto de caminhamentos conjuntos pelo local, para avaliação do potencial arqueológico e troca de informações, o que era utilizado mais proeminentemente ao longo do texto. De modo geral, esses relatos, informações e interpretações ficam reservados nos relatórios em um capítulo ou seção separada da descrição do campo, na qual se inserem as interpretações dos(as) arqueólogos(as). Desse modo, as informações e interpretações dos moradores não fazem parte formalmente da produção do conhecimento arqueológico propriamente dito. Além disso, as falas selecionadas da população quase nunca refletem ou demonstram suas opiniões sobre o impacto do empreendimento para elas e para o local.

O ocultamento e falta de agência simétrica das comunidades atingidas e grupos indígenas nos processos de licenciamento ambiental não significa que esses coletivos estejam ausentes das redes sociotécnicas que constituem essa ferramenta estatal. $\mathrm{O}$ recorte da rede proposto na minha etnografia, focando-me nas falas dos cientistas, reafirma os locais privilegiados de fala e tomada de decisões no contexto do licenciamento ambiental desses especialistas. Essa "traição etnográfica e silenciamento do outro" (Gerhardt, 2016) foi uma decisão pensada e calculada dentro do escopo possível da dissertação de mestrado. Entretanto, deve-se refletir sobre a questão de até onde esses grupos querem se adentrar nesses processos do modo como estão estabelecidos. Povos indígenas já demonstraram que suas demandas não cabem nos termos desses processos burocráticos, estatais e científicos do licenciamento ambiental. O que faz com que eles mesmos produzam seus estudos, documentos e resultados (Mantovanelli, 2016). A agência e os efeitos viram de lado, partem deles. O que não quer dizer que não se devam procurar formas de participação mais 
amplas e plurais desses grupos nesse contexto, contudo, devem-se notar os limites e as possibilidades.

\section{Conclusão}

A partir da perspectiva das redes sociotécnicas, da antropologia da ciência e da burocracia, a etnografia da prática arqueológica apresentada aqui teve como objetivo pensar essa disciplina no licenciamento ambiental como participante de um processo muito maior do que a identificação e o registro de sítios e bens arqueológicos. Ao cartografar na rede os atores, suas agências e mediações, percebemos como fatos científicos, entidades, decisões, conhecimento arqueológico e patrimônio cultural são fabricados - ao mesmo tempo em que notamos as vozes e os atores silenciados e ocultados nesse contexto. Ao refletir sobre a prática científica juntamente, e sendo coproduzida, à política e aos trâmites burocráticos, temos um panorama mais amplo de como o licenciamento ambiental é uma arena de disputas, no qual tanto a ciência quanto o estado, a burocracia e o patrimônio estão constantemente em constituição, em ação.

Pesquisar, analisar e debater sobre o tema da arqueologia no licenciamento ambiental não pode fugir de um contexto político, no qual as diferentes práticas científicas vêm sendo atacadas por diversos segmentos da política brasileira e da mídia. A arqueologia, por exemplo, é pintada muitas vezes como a culpada pelo atraso e pela não efetivação de diversos empreendimentos para o "desenvolvimento nacional” devido a "caquinhos" que não importam a ninguém. Inclusive há diversas propostas legislativas para modificar o licenciamento ambiental e até retirar a necessidade de pesquisas arqueológicas nesse âmbito ${ }^{14}$.

Etnografar a prática arqueológica no licenciamento ambiental é assim, não um ataque ou uma tentativa de deslegitimar a produção do conhecimento científico e as suas "verdades essenciais", mas sim um modo de enriquecer e aumentar dimensões cruciais da prática arqueológica que estão negligenciadas (Edgeworth, 2010:55). Pensar e analisar o modo como o conhecimento científico é produzido, ainda mais aquele que trata do passado e de populações subalternas, como povos indígenas, não é apenas um imperativo da ciência em si, mas também um posicionamento ético frente a que tipo de conhecimento é produzido e como - a partir do que e junto a quem - ele é fabricado e divulgado. Etnografar a prática arqueológica é se engajar na questão sobre como essa ciência atua no mundo (Castañeda, 2014). Mesmo com os diversos constrangimentos legais, burocráticos e científicos que apresentei acima, 
os(as) interlocutores(as) da pesquisa, cientes dessas restrições, não abdicaram de se pensar, apresentar e atuar enquanto atores políticos e sociais. Roberta, dona de uma empresa de arqueologia, reflete sobre a potencialidade epistemológica da arqueologia, seu papel político e social:

Eu acho que o arqueólogo é um, é um... desagradável (risos). Porque eu acho que é uma das profissões mais políticas. A gente tem um grande poder nas mãos. $\mathrm{O}$ que a gente faz é desenterrar coisas que pessoas propositadamente enterraram no passado, ou que propositadamente abandonaram no passado, ou que foram abandonadas pelo propósito de alguém que expulsou, explorou, excluiu uma determinada população. Então a gente é o cara que vai lá e diz "tá tudo errado", sabe (risos). Isso é um baita de um poder político. A gente pode dar voz a todas essas populações que desapareceram de determinado lugar e um determinado momento por algum motivo.

Entretanto, há um grande abismo entre "para que $(\mathrm{m})$ queremos fazer arqueologia" e "para que(m) fazemos arqueologia”. No contexto do licenciamento ambiental pode-se ver mais claramente como paradigmas científicos tecno-tipológicos, juntamente a legislações, documentos burocráticos e interesses políticos do estado, restringem a atuação dessa ciência a mera identificação e registro de uma cultura material distanciada das populações do entorno ou indígenas. Se os ambientalistas no licenciamento ambiental são os “porta-vozes da natureza” (Bronz, 2011:291), por serem capazes de transformar a natureza em projetos, investimentos e dados a serem analisados para tomadas de decisões acerca de projetos desenvolvimentistas, os(as) arqueólogos(as), nesse mesmo contexto, são os(as) porta-vozes do patrimônio. Para Joaquim, refletindo a partir de suas duas décadas atuando no licenciamento ambiental, a relação dos(as) arqueólogos(as) com o patrimônio é, por um lado, como Midas, pois podem transformar as coisas em patrimônio, e por outro, como bactérias necrófagas, necessitando do impacto e da destruição - mesmo que seja via uma escavação - desse patrimônio.

A pergunta que fica, tanto para mim quanto para os(as) interlocutores(as), é como transferir o discurso povoado de pessoas, de interpretações e demandas da comunidade frente aos trabalhos e ao patrimônio arqueológico, para os relatórios técnicos, para esses documentos burocráticos que passam por tantas mediações, constrangimentos legais e políticos. Desse modo, entender e mapear esses diferentes trâmites que envolvem a prática da arqueologia no licenciamento ambiental 
pode ser um meio pelo qual pensar, procurar e construir novas possibilidades de ação, de confecção de relatórios e de construção de patrimônio, para que a arqueologia não seja apenas mais um protocolo formal para projetos desenvolvimentistas.

Enquanto nós, arqueólogas e arqueólogos, evitarmos discutir a participação dos sítios arqueológicos na produção e reprodução da vida social no presente; enquanto não discutirmos as relações atuais entre pessoas e mundo material, nós seguiremos abdicando do potencial da disciplina para ressaltar formas locais e tradicionais de concepção e expressão de projetos alternativos para um dado território - muito mais que propriedade cobiçada pelos projetos capitalistas. O modo como lidamos com as interações atuais entre as pessoas e os sítios arqueológicos contribui, sobremaneira, com a marginalização de coletivos locais no processo de licenciamento ambiental. Os relatórios técnicos criam uma distância artificial e impossível entre objetos arqueológicos e pessoas, localizando a dinâmica social da evidência arqueológica apenas no passado, e num passado distante ou longínquo - posto que ainda discutimos, inclusive, quais são os limites que separam o arqueológico do contemporâneo (se cronologia, tecnologia, notabilidade ou uma combinação delas). Herança positivista, a crença na distância intransponível entre passado e presente, entre produtores/usuários e observadores da evidência arqueológica, dificulta a percepção espontânea e inviabiliza a valorização de relações afetivas ou espirituais que populações que não possuem nenhuma "ancestralidade comprovada" possam estabelecer com os sítios arqueológicos de seu território (Ribeiro, 2015:183).

A pesquisa aqui apresentada trabalhou também na direção de pensar e refletir sobre a responsabilidade social, ética, política e científica (mas não como se fossem campos separados) dos(as) arqueólogos(as) e de seus relatórios em uma prática cada vez mais do, de e no conflito. Como visto, há muito mais em jogo do que seguir os requisitos mínimos propostos por lei. A arqueologia, principalmente no contexto do licenciamento ambiental, é uma prática que deve saber identificar e lidar com conflitos, impactos, riscos, danos e violências de todos os tipos. Vivemos e habitamos em uma terra que está sendo modificada e destruída pelas nossas ações, logo, a arqueologia se transforma de uma ciência que apenas trata do passado, em uma ciência, em uma prática política, que se engaja com e por um futuro: "Trata-se de uma questão de tomar conhecimento de "fatos desconfortáveis" relacionados a questões urgentes que dizem respeito ao próprio solo habitado por todos" (Latour, 2014:20). 
Recebido: 29/07/2018

Aprovado: 26/11/2018

Marcus A. S. Wittmann é mestre em Antropologia Social pela Universidade Federal do Rio Grande do Sul (PPGAS/UFRGS). Possui graduação em História pela Pontifícia Universidade Católica do Rio Grande do Sul (PUCRS) e especialização em Arqueologia Brasileira pelo Instituto de Arqueologia Brasileira (IAB). É pesquisador associado ao Núcleo de Antropologia das Sociedades Indígenas e Tradicionais (NIT/UFRGS) e do Laboratório de Arqueologia e Etnologia (LAE/ UFRGS). ORCID: 0000-0002-9020-9945 Contato: wittmann.marcus@gmail.com

\section{Notas}

1. Cabe ressaltar que o número de protocolos não faz referência direta ao número de empreendimentos licenciados e nem ao número de portarias de pesquisa emitidas pelo Iphan.

2. Devido ao tempo curto de um Mestrado, não foi possível fazer a etnografia de um campo arqueológico no licenciamento ambiental. Seguir todos os trâmites e temporalidades de um projeto específico, desde seu início até conclusão, poderia levar mais do que dois anos. Deste modo, foi escolhida uma abordagem mais ampla sobre esse tema através de entrevistas e análises de processos.

3. Ordem de Serviço 02 de 2016, a qual instaura, a partir da IN 01/15, modelos de parecer técnico para projetos e relatórios de arqueologia no âmbito do licenciamento ambiental.

4. A categoria “Nível III” faz referência ao Anexo II da Instrução Normativa 01/2015, a qual divide diferentes empreendimentos, dependendo de seu tamanho e impacto no solo, em diferentes níveis (Não se Aplica, Nível I, II, III e IV), os quais possuem especificidades no que tange ao tipo de trabalho e pesquisas arqueológicas necessárias.

5. Vale ressaltar que a definição de impacto ao patrimônio arqueológico no licenciamento ambiental, mas também de forma geral, se dá pela avaliação material e física dos artefatos e sítios, e não no que tange à imaterialidade deles ou questões cosmo-ontológicas que podem estar envolvidas em suas relações com grupos indígenas, por exemplo.

6. A “chefia”, nesse caso, é a(o) superintendente do Iphan, as(os) quais, geralmente, são arquitetas(os).

7. Há um grande problema nessa solicitação da IN, pois o banco de dados no site do Iphan dos sítios arqueológicos registrados é incompleto e defasado. Não há uma atualização recorrente de novos registros e, para a grande maioria dos sítios cadastrados, não há a indicação da localização georreferenciada dos mesmos.

8. Concursos para arqueólogos efetivos no IPHAN são bem raros. Ocorreu um em 2009 e outro 
apenas em 2018. Durante esse tempo foram contratados apenas arqueólogos para atuarem durante alguns poucos anos no setor de arqueologia.

9. Há uma dificuldade em mapear trabalhos acadêmicos que são resultados de pesquisas feitas no licenciamento ambiental, pois muitos não citam esse aspecto nas publicações.

10. É claro que também não se pode tratar a arqueologia como algo homogêneo e uno, como se não houvesse outras concepções, práticas e compromissos dentro dessa ciência. Entretanto, ao mesmo tempo em que existem arqueologias colaborativas, indígenas e simétricas, elas continuam sendo, de um modo ou de outro, frutos de uma concepção ocidental moderna.

11. Apenas um dos projetos analisados trazia o histórico da região sem essa divisão, apresentando um fluxo contínuo que abarcava a história indígena de longa duração e a história da colonização europeia. 12. Software utilizado para gerenciamento de banco de dados e preenchimento digital da ficha de registro.

13. A avaliação das atividades pela comunidade escolar, pelos professores ou pelo grupo de pessoas abarcado é solicitada pelo Iphan. Contudo, geralmente o que é apresentado são pequenas fichas de avaliação para que os participantes respondam algumas poucas perguntas, às vezes de múltipla escolha, sobre a atividade e sobre a arqueologia de modo geral, sem uma análise mais aprofundada do impacto dessas ações na comunidade.

14. Proposta de emenda constitucional 65/2012, a qual dá anuência direta a qualquer obra pública entendida como estratégica para o desenvolvimento do país; Proposta da Associação Brasileira de Entidades Estaduais de Meio Ambiente (ABEMA) para alteração da Resolução CONAMA 01 / 86, retirando o aspecto cultura do licenciamento ambiental; Projeto de Lei do Senado 654/2015, que propõe uma licença única de duração de oito meses, usurpando a competência de órgãos como o Iphan; Projeto de Decreto Legislativo 540/2016, que visa sustar a aplicação da Instrução Normativa $01 / 2015$, deixando a arqueologia sem um regimento voltado especificamente para a prática no licenciamento ambiental; e a Lei Geral do Licenciamento (Projeto de Lei 2.941/2011), a qual apresenta uma proposta simplificada do processo licenciatório, suprindo o papel do Iphan. Essas propostas não foram promulgadas, mas também não estão completamente fora de cogitação no âmbito jurídico e legal. Já no Rio Grande do Sul, foi publicada em agosto de 2017 a Resolução 357 do Conselho Estadual do Meio Ambiente (CONSEMA), a qual define que o IPHAN só deve se manifestar no processo licenciatório caso já existam bens culturais acautelados na área diretamente afetada pelo empreendimento, excluindo assim a possibilidade de pesquisas arqueológicas que venham a descobrir novos sítios arqueológicos que não aqueles já identificados e registrados no âmbito federal. Em agosto de 2017, a Secretaria Estadual do Meio Ambiente (SEMA) do Mato Grosso também promulgou uma resolução com o mesmo teor.

\section{Referências bibliográficas}

BRONZ, Deborah. 2011. Empreendimentos e empreendedores: formas de gestão, classificações e conflitos a partir do licenciamento ambiental, Brasil, século XXI. Tese [Doutorado em Antropologia Social]. Rio de Janeiro: Museu Nacional.

BRONZ, Deborah. 2013. “'O Estado não sou eu’. Estratégias empresariais no licenciamento ambiental de grandes empreendimentos industriais”. CAMPOS-Revista de Antropologia Social, 
Dossiê Antropologia e Desenvolvimento, 14 (1/2):37-55.

BRONZ, Deborah; FRAIMAN, Ricardo. 2009. “Grupos de Interés: análisis crítico sobre el establecimiento del método en la gestión empresarial de los Grandes Proyectos Industriales del Brasil”. Revista Latinoamericana de Ciencias Sociales, 1:10-31.

BUENO, Lucas de Melo Reis. 2011. “Arqueologia, patrimônio e sociedade: quem define a agenda?”. Revista Esboços, 18 (26): 55-72.

CASTAÑEDA, Quetzil E. 2014. "Situating Activism in Archaeology: The mission of science, the activist, and the archaeological record”. In: Sonya Atalay; Lee Rains Clauss; Randall McGuire; John R. Welch (ed.), Transforming Archaeology: Activist Practices and Prospects. Walnut Creek (CA): Left Coast Press. pp. 61-90.

EDGEWORTH, Matt. 2003. Acts of Discovery: an Ethnography of Archaeological Practice. Oxford: British Archaeological Reports.

EDGEWORTH, Matt. 2006. "Preface". In: Matt Edgeworth (org.), Ethnographies of Archaeological Practice: cultural encounters, material transformation. Oxford: Alta Mira Press. pp. xi-xvi. EDGEWORTH, Matt. 2010. "On the boundary: new perspectives from ethnography of archaeology”. In: Duncan Garrow, Thomas Yarrow (ed.), Archaeology and Anthropology: understanding similarity, exploring difference. Oxford: Oxbow Books. pp. 54-68.

FERREIRA, Lúcio Menezes. 2010. Território Primitivo: a institucionalização da arqueologia no Brasil (1870-1917). Porto Alegre: EDIPUCRS.

GERHARDT, Cleyton Henrique. 2016. “Traições etnográficas e o ocultamento do outro na evidenciação da fala competente: sobre violências epistêmicas em situação de alteridade mínima”. Anais da $30^{\circ}$ Reunião Brasileira de Antropologia, GT 35: Fantasmas dentro da máquina? O ofício antropológico dentro e na órbita da institucionalidade estatal: 1-35.

HULL, Matthew. 2012. "Documents and bureaucracy". Annual Review of Anthropology, 41:251267.

JASANOFF, Sheila. 2006. “The idiom of co-production”. In: Sheila Jasanoff. States of Knowledge: The co-production of science and social order. London: Routledge. pp. 1-12.

REIS, José Alberione dos. 2010. “Não pensa muito que dói”: um palimpsesto sobre teoria na arqueologia brasileira. Porto Alegre: EDIPUCRS.

RIBEIRO, Loredana. 2015. "Empreendimentos econômicos, violação de direitos humanos e o silêncio da arqueologia no Brasil”. Revista de Arqueologia, 28(2):172-186.

LATOUR, Bruno. 2004. "Por uma antropologia do centro”. Mana, 10, 2: 397- 414.

LATOUR, Bruno. 2011. Ciência em Ação: como seguir cientistas e engenheiros sociedade afora. 2. ed. São Paulo: Unesp.

LATOUR, Bruno. 2014. "Para distinguir amigos e inimigos no tempo do Antropoceno". Revista de Antropologia, 57(1):11-31.

LOWENKRON, Laura, FERREIRA, Letícia. 2014. "Anthropological perspectives on documents: Ethnographic dialogues on the trail of police papers". Vibrant, 11(2):75-111.

MANTOVANELLI, Thaís. 2016. “Os Xikrin da Terra Indígena Trincheira-Bacajá e os Estudos Complementares do Rio Bacajá: Reflexões sobre a elaboração de um Laudo de Impacto Ambiental”. 
Horizontes Antropológicos, 22 (46):159-188.

PELLINI, José Roberto. 2014. "Os sacerdotes da verdade: ética e o conceito de registro arqueológico”. Habitus, 12(2): 291-306.

WITTMANN, Marcus Antonio Schifino. 2017. "Esgotos, relatórios e arqueologia: etnografando processos de licenciamento ambiental para o saneamento básico". Cadernos de Campo (USP), 1(26): 150-167.

WITTMANN, Marcus Antonio Schifino. 2018. Entre cientistas, burocracias e uma coisa chamada patrimônio: uma etnografia da prática arqueológica no licenciamento ambiental. Dissertação [Mestrado em Antropologia Social]. Porto Alegre: UFRGS.

WITTMANN, Marcus Antonio Schifino, BAPTISTA DA SILVA, Sérgio. 2017. "Relatórios técnicos de arqueologia no licenciamento ambiental: a materialização do patrimônio como ferramenta estatal”. Anais da VI Reunião de Antropologia da Ciência e da Tecnologia, 3(1): 25-44. 
Arqueologia no licenciamento ambiental: uma etnografia de cientistas e suas burocracias

Resumo: Este artigo tem como objetivo mapear as redes sociotécnicas que compõem e são compostas ao longo do processo de licenciamento ambiental, no que tange às práticas arqueológicas e aos trâmites burocráticos referentes a elas. Seguindo cientistas e suas práticas, burocratas e seus documentos, pode-se ver como a constituição do patrimônio arqueológico é um fenômeno entremeado por disputas políticas, tanto quanto por teorias e métodos científicos. Esta pesquisa é fruto de uma dissertação de mestrado, durante a qual foram entrevistados vinte e um arqueólogos de diferentes gerações e com diferentes experiências e cargos, além da análise de sessenta processos de arqueologia no licenciamento ambiental para diferentes empreendimentos no estado do Rio Grande do Sul, Brasil.

Palavras-chave: Etnografia da prática arqueológica; licenciamento ambiental; antropologia da ciência.
Archaeology in environmental licensing: an ethnography of scientists and their bureaucracies

Abstract: This paper has the objective of mapping the sociotechnical networks that compose and are composed through the processes of environmental licensing, on what regards the archaeological practices and the bureaucratic procedures related to them. Following scientists and their practices, bureaucrats and their documents, we can see how the constitution of the archaeological heritage is a phenomenon entangled by political disputes as much as by scientific theories and methods. This research is the result of a master's thesis, during which twenty-one archaeologists of different generations and with different experiences and positions were interviewed, as well as the analysis of sixty archaeological processes in environmental licensing for different enterprises in the state of Rio Grande do Sul, Brazil.

Keywords: Ethnography of archaeological practice; environmental licensing; anthropology of science. 